\title{
Somatic MEN1 gene mutation does not contribute significantly to sporadic pituitary tumorigenesis
}

\author{
Jacques Poncin ${ }^{1}$, Achille Stevenaert ${ }^{2}$ and Albert Beckers ${ }^{3}$ \\ ${ }^{1}$ Departments of Medical Genetics, ${ }^{3}$ Endocrinology, and ${ }^{2}$ Surgery, University Hospital, University of Liège, 4000 Liège, Belgium \\ (Correspondence should be addressed to Jacques Poncin, Laboratoire de Génétique Moléculaire, Centre Hospital Universitaire de Liège, \\ Tour de Pathologie Sart-Tilman, 4000 Liege, Belgique; Email: jponcin@chu.ulg.ac.be)
}

\begin{abstract}
Pituitary adenomas are a common manifestation of multiple endocrine neoplasia type 1 (MEN1) but most of them occur sporadically. There are only a few well defined genetic abnormalities known to occur in these sporadic tumours. The MEN1 gene located on 11q13 has recently been cloned and allelic deletion and mutation analysis studies have implicated the MEN1 gene in a significant fraction of the sporadic counterparts of typical MEN1 neoplasms (parathyroid tumours, insulinomas and gastrinomas).

To determine if MEN1 gene inactivation is also involved in the development of sporadic pituitary adenomas, allelic deletions of chromosome 11q13 and MEN1 gene mutations and polymorphisms were assessed in 35 sporadic tumours of the anterior pituitary ( 9 prolactin-secreting, $8 \mathrm{GH}$-secreting, 3 TSH-secreting, 2 TSH/GH-secreting, 4 Cushing, 9 silent). Thirty-one tumours were found to be heterozygous for at least one MEN1 intragenic polymorphism (25 cases) or for a flanking gene polymorphism ( 6 cases). The remaining tumours were not informative.

No mutations were found in any tumour except in one prolactinoma which was homozygous or hemizygous for a mutation $(1-117 \mathrm{C} \rightarrow \mathrm{T})$ in a region close to the promoter. Unfortunately, blood or normal tissue was not available in this case.

Our data show that somatic MEN1 mutations do not contribute significantly to tumorigenesis of sporadic pituitary adenomas and suggest that mutation of other genes are likely to contribute to the pathogenesis of these tumours.
\end{abstract}

European Journal of Endocrinology 140 573-576

\section{Introduction}

Pituitary adenomas are a common manifestation of multiple endocrine neoplasia type 1 (MEN1) but most of them occur sporadically. To date, only a few genetic abnormalities have been described in these sporadic tumours.

For example, a mutation in the GSP gene occurs in about $1 / 3$ of somatotrophic adenomas, but is rarely found in other pituitary tumour types (1). Other candidate oncogenes and tumour suppressor genes may play a role in the formation of pituitary tumours, but to date the pathogenesis of most tumours remains unexplained (for a review, see (2)).

The MEN1 gene located on chromosome 11q13 has recently been cloned $(3,4)$, and allelic deletion and mutation analysis studies have implicated the MEN1 gene in a significant fraction of the sporadic counterparts of typical MEN1 neoplasms (parathyroid tumours, carcinoid tumours of the lung, gastrinomas and insulinomas) (5-7). To investigate whether MEN1 gene inactivation is involved in the development of sporadic pituitary adenomas, loss of heterozygosity (LOH) for
$11 \mathrm{q} 13$ and MEN1 gene mutations was assessed in 35 sporadic tumours of the anterior pituitary.

\section{Materials and methods}

\section{Tissue collection and DNA preparation}

Thirty-five cryopreserved anterior pituitary tumours from the files of the Department of Endocrinology were included in this study. A MEN1 syndrome was excluded by familial anamnesis and by measurements in each patient of parathyroid hormone, $\mathrm{Ca}^{++}$, phosphate, gastrin, pancreatic polypeptide and adrenal hormones serum levels.

The sample comprised 9 prolactin (PRL)-secreting adenomas, 8 growth hormone (GH)-secreting adenomas, 3 thyrotrophin (TSH)-secreting adenomas, 2 TSH/ $\mathrm{GH}$-secreting adenomas, 9 silent adenomas and 4 ACTH-secreting adenomas.

Tissue was frozen in liquid nitrogen immediately after surgical excision and stored at $-70^{\circ} \mathrm{C}$. Genomic DNA was extracted by standard methods. 


\section{Mutation and intragenic polymorphism analysis}

Exons 1-10 of the MEN1 gene were amplified in a volume of $50 \mu \mathrm{l}$ containing $10 \mathrm{mmol} / \mathrm{l}$ Tris $-\mathrm{HC} 1 \mathrm{pH}$ $8.3), 50 \mathrm{mmol} / \mathrm{l} \mathrm{KC1}, 1.5 \mathrm{mmol} / \mathrm{l} \mathrm{MgCl}_{2}, 200 \mu \mathrm{mol} / \mathrm{l}$ dNTPs, $0.5 \mu \mathrm{mol} / \mathrm{l}$ of each of the primers, 2.5 units Taq polymerase (Perkin-Elmer Cetus, Foster City, CA, USA) and $200 \mathrm{ng}$ genomic DNA. Samples were heated at $94^{\circ} \mathrm{C}$ for $7 \mathrm{~min}$. Forty PCR cycles $\left(1 \mathrm{~min}\right.$ at $94^{\circ} \mathrm{C}, 1 \mathrm{~min}$ at the relevant annealing temperature (Table 1 ), and $2 \mathrm{~min}$ at $72{ }^{\circ} \mathrm{C}$ ) were then performed. The DNA synthesis step of the final cycle at $72{ }^{\circ} \mathrm{C}$ was extended to $7 \mathrm{~min}$. To secure detection of most splice site mutations, the PCR primers (Table 1) were designed so that each exon and at least 40 bases of its flanking sequences were contained in the amplified fragment.

The PCR products were controlled by electrophoresis in $1 \%$ agarose, purified using the QIAquick PCR purification kit (Qiagen $\mathrm{GmbH}$, Hilden, Germany) and sequenced using Dye Terminator Cycle Sequencing chemistry with AmpliTaq DNA Polymerase FS (ABI PRISM Dye Terminator Cycle Sequencing kit, PerkinElmer, Foster City, CA, USA) and one of the primers described above. The sequencing reaction mixture was subjected to 25 repeated rounds of denaturation for $30 \mathrm{~s}$ at $96^{\circ} \mathrm{C}$, annealing for $15 \mathrm{~s}$ at $50^{\circ} \mathrm{C}$, and synthesis steps for $4 \mathrm{~min}$ at $60^{\circ} \mathrm{C}$. The extension products were purified by ethanol precipitation. The pellets were briefly dried and resuspended in $4 \mu \mathrm{l} 5 \mathrm{mmol} / \mathrm{l}$ EDTA ( $\mathrm{pH} 8.0$ ), 80\% formamide. The samples were heated at $95^{\circ} \mathrm{C}$ for two min, loaded on $6 \%$ polyacrylamide denaturing gels and electrophoresed for $7 \mathrm{~h}$ at $1600 \mathrm{~V}$ in a ABI PRISM 377 DNA Sequencer (Perkin-Elmer). Both strands of the PCR products were sequenced in each case. Sequence comparisons were performed by use of the Sequence Navigator software (Perkin-Elmer).

\section{LOH testing with MEN1 flanking markers}

Samples were screened for $\mathrm{LOH}$ with the microsatellite polymorphic markers D11S449, D11S1883, and D11S1889 flanking the MEN1 gene (8). The target DNA sequences were amplified by PCR in a volume of $50 \mu \mathrm{l}$ containing $10 \mathrm{mmol} / \mathrm{l}$ Tris $-\mathrm{HCl}(\mathrm{pH}$ 8.3), $50 \mathrm{mmol} / \mathrm{l} \mathrm{KCl}, 1.5 \mathrm{mmol} / \mathrm{l} \mathrm{MgCl}_{2}, 200 \mu \mathrm{mol} / \mathrm{l} \mathrm{dNTPs}$, $2 \mu \mathrm{mol} / \mathrm{l}$ fluorescent-dUTP (TAMRA-, R110-, or R6GdUTP, Perkin-Elmer), $1 \mu \mathrm{mol} / \mathrm{l}$ of each of the primers, 2.5 units Taq polymerase (Perkin-Elmer Cetus) and $200 \mathrm{ng}$ genomic DNA. Samples were heated at $94{ }^{\circ} \mathrm{C}$ for $3 \mathrm{~min}$. Thirty-five PCR cycles $\left(1 \mathrm{~min}\right.$ at $94^{\circ} \mathrm{C}, 1 \mathrm{~min}$ at the relevant annealing temperature and $2 \mathrm{~min}$ at $72{ }^{\circ} \mathrm{C}$ ) were then performed. The DNA synthesis step of the final cycle at $72{ }^{\circ} \mathrm{C}$ was extended to $7 \mathrm{~min}$. The products were purified by centrifugation on a MicroCon-30 spin column (Amicon Inc., Beverly, MA, USA) and were analysed on $6 \%$ polyacrylamide denaturing gels in an ABI PRISM 377 DNA Sequencer (Perkin-Elmer). Purified PCR product $(0.5-1.5 \mu \mathrm{l})$ was combined with $2.5 \mu \mathrm{l}$ formamide and $0.5 \mu \mathrm{l}$ of a fluorescent size marker (ROX 500, Perkin-Elmer). After denaturation at $90^{\circ} \mathrm{C}, 2 \mu \mathrm{l}$ of the mixture were loaded on the gel and electrophoresed for $2.5 \mathrm{~h}$ at $3000 \mathrm{~V}$. The fluorescent gel data collected during the run were automatically analysed by the Genescan analysis program (Perkin-Elmer) at the end of the run. Each fluorescent peak was quantitated in terms of size (in base pairs), peak height and peak area.

Table 1 Oligonucleotides used for PCR amplification and PCR parameters of MEN1 gene exons.

\begin{tabular}{|c|c|c|c|}
\hline Exon & PCR primers, $5^{\prime} \rightarrow 3^{\prime}$ & Position in MEN1 gene & Annealing temperature $\left({ }^{\circ} \mathrm{C}\right)$ \\
\hline $1+$ upstream & $\begin{array}{l}\text { TTTTTCCTCATAACTTGCCGACCG } \\
\text { GTCCCGCCCCTAGGGTCGCA }\end{array}$ & $\begin{array}{l}1501 \\
1817\end{array}$ & 65 \\
\hline 2 & $\begin{array}{l}\text { GGGGCGGGTGGAACCTTAGCGGA } \\
\text { ACAGTTCTTAAAAGGGTTCTGTAAACC }\end{array}$ & $\begin{array}{l}2180 \\
2816\end{array}$ & 67 \\
\hline 3 & $\begin{array}{l}\text { GAGTGGGAGGGCGTGTGG } \\
\text { CAGTATGAAGGGGACAAGG }\end{array}$ & $\begin{array}{l}4206 \\
4544\end{array}$ & 55 \\
\hline 4 & $\begin{array}{l}\text { ACAGGGTGGGCCATCATGAGACAT } \\
\text { AGCAAGTCAAGTCTGGCCTAGCC }\end{array}$ & $\begin{array}{l}4670 \\
4896\end{array}$ & 65 \\
\hline $5+6$ & $\begin{array}{l}\text { ACCCGTTCTCСTCCСTGTTC } \\
\text { AAAGTTCTCTTCTCATCTGCCC }\end{array}$ & $\begin{array}{l}5125 \\
5473\end{array}$ & 59 \\
\hline 7 & $\begin{array}{l}\text { GGACTCCCTGGGATCTTCCTGTG } \\
\text { GGACGAGGGTGGTTGGAAACTG }\end{array}$ & $\begin{array}{l}5911 \\
6233\end{array}$ & 67 \\
\hline 8 & $\begin{array}{l}\text { TGGTGAGACCCCTTCAGACCCTAC } \\
\text { CCATCCCTAATCCCGTACATGC }\end{array}$ & $\begin{array}{l}6577 \\
6855\end{array}$ & 64 \\
\hline 9 & $\begin{array}{l}\text { GGGGTGAGTAAGAGACTGATC } \\
\text { GTCTGACAAGCCCGTGGCTGC }\end{array}$ & $\begin{array}{l}7149 \\
7426\end{array}$ & 61 \\
\hline 10 & $\begin{array}{l}\text { CCATCCCCTTCGGTGCCGAT } \\
\text { GGCTCAGAGTTGGGGGACTAA }\end{array}$ & $\begin{array}{l}7453 \\
8125\end{array}$ & 62 \\
\hline
\end{tabular}

For each exon, the primer at the $5^{\prime}$ end is reported on the first line, and that at the $3^{\prime}$ end on the second line. 


\section{Results}

\section{Mutation screening in pituitary tumours}

The MEN1 transcripted sequence was screened for mutations by automatic sequence analysis in 35 sporadic anterior pituitary tumours including 26 hormonesecreting and 9 non-secreting tumours (Table 2). No mutations were found in any tumour except in one prolactinoma which was homozygous or hemizygous for a mutation $(1-117 \mathrm{C} \rightarrow \mathrm{T})$ in a region close to the transcription start site.

\section{Polymorphisms of the MEN1 gene and intragenic screening for $\mathrm{LOH}$}

Six relatively common polymorphisms were identified and their frequencies were evaluated in 120 normal chromosomes. These were T-A at nucleotide 76 of exon 1 (45\% T, 55\% A), C-G in intron 116 nucleotides upstream of exon $2(80 \%$ C, 20\% G), S145S (AGC/AGT) (6\%), R171Q (CGG/CAG) (3.7\%), D418D (GAC/GAT) (42\%), A541T (GCA/ACA) (2.5\%). The first two of these polymorphisms (76: T-A and 88-16: C-G) were not described previously. They are highly informative and were therefore used as intragenic markers for $\mathrm{LOH}$ screening. Most of the tumors (25/35) were heterozygous for at least one of these intragenic polymorphisms.

\section{LOH analysis with flanking markers}

The 10 tumours which were uninformative for the MEN1 intragenic polymorphisms were screened for $\mathrm{LOH}$ using the flanking markers D11S1889, D11S449, and D11S1883. Six of the tumours were heterozygous for at least one marker.

Table 2 Results of the polymorphisms analysis for 35 pituitary adenomas.

\begin{tabular}{|c|c|c|c|c|c|c|c|c|}
\hline \multirow[b]{2}{*}{ Tumour and type } & \multicolumn{5}{|c|}{ MEN1 gene polymorphisms } & \multicolumn{3}{|c|}{ Flanking polymorphisms } \\
\hline & Mutation & nt 76 & nt $88-16$ & D418D & S145S & D11S1889 & D11S449 & D11S1883 \\
\hline $1 \mathrm{PRL}^{*}$ & 1-117:T & & & & & & & \\
\hline $2 \mathrm{PRL}$ & & & $\mathrm{H}$ & & & & & \\
\hline $3 \mathrm{PRL}$ & & $\mathrm{H}$ & & & & & & \\
\hline $4 \mathrm{PRL}$ & & $\mathrm{H}$ & & & & & & \\
\hline $5 \mathrm{PRL}$ & & $\mathrm{H}$ & & & & & & \\
\hline $6 \mathrm{PRL}^{*}$ & & & & & & & & \\
\hline $7 \mathrm{PRL}$ & & $\mathrm{H}$ & & & & & & \\
\hline $8 \mathrm{PRL}^{*}$ & & & & & & $\mathrm{H}$ & $\mathrm{H}$ & \\
\hline $9 \mathrm{PRL}$ & & $\mathrm{H}$ & $\mathrm{H}$ & & & & & \\
\hline $11 \mathrm{TSH} / \mathrm{GH}$ & & & & $\mathrm{H}$ & $\mathrm{H}$ & & & \\
\hline $12 \mathrm{GH}^{*}$ & & & & & & & $\mathrm{H}$ & \\
\hline $13 \mathrm{GH}$ & & $\mathrm{H}$ & & $\mathrm{H}$ & & & & \\
\hline $14 \mathrm{GH}$ & & $\mathrm{H}$ & & & & & & \\
\hline $15 \mathrm{TSH} / \mathrm{GH}$ & & & & $\mathrm{H}$ & & & & \\
\hline $16 \mathrm{TSH}^{*}$ & & & & & & & & \\
\hline $17 \mathrm{TSH}$ & & & & $\mathrm{H}$ & & & & \\
\hline $18 \mathrm{GH}^{*}$ & & & & & & $\mathrm{H}$ & & $\mathrm{H}$ \\
\hline $19 \mathrm{GH}$ & & $\mathrm{H}$ & & & & & & \\
\hline $20 \mathrm{TSH}$ & & & $\mathrm{H}$ & $\mathrm{H}$ & & & & \\
\hline $21 \mathrm{GH}$ & & & & & $\mathrm{H}$ & & & \\
\hline $22 \mathrm{GH}$ & & & & $\mathrm{H}$ & & & & \\
\hline $23 \mathrm{GH}$ & & $\mathrm{H}$ & & & & & & \\
\hline 25 NS* $^{*}$ & & & & & & & & \\
\hline 26 NS & & $\mathrm{H}$ & & $\mathrm{H}$ & & & & \\
\hline $27 \mathrm{NS}^{*}$ & & & & & & $\mathrm{H}$ & & \\
\hline 28 NS & & $\mathrm{H}$ & & $\mathrm{H}$ & & & & \\
\hline 29 NS & & $\mathrm{H}$ & & $\mathrm{H}$ & & & & \\
\hline $30 \mathrm{NS}^{*}$ & & & & & & $\mathrm{H}$ & & \\
\hline $31 \mathrm{NS}$ & & & & $\mathrm{H}$ & & & & \\
\hline 32 NS & & $\mathrm{H}$ & & & & & & \\
\hline 33 NS & & & & $\mathrm{H}$ & & & & \\
\hline 34 АCTH & & & & $\mathrm{H}$ & & & & \\
\hline 35 ACTH $^{*}$ & & & & & & & & $\mathrm{H}$ \\
\hline $36 \mathrm{ACTH}$ & & & & & $\mathrm{H}$ & & & \\
\hline 37 АCTH & & & & & $\mathrm{H}$ & & & \\
\hline
\end{tabular}

PRL, prolactinoma; TSH, TSH-secreting adenoma; $\mathrm{GH}, \mathrm{GH}$-secreting adenoma; NS, non-secreting adenoma; $\mathrm{H}$, heterozygosity for the considered marker.

* The ten tumours which were uninformative for the MEN1 intragenic polymorphisms and which were screened for LOH with flanking markers. 


\section{Discussion}

The pathogenesis of pituitary tumours remains unexplained in most cases. The MEN1 gene has been cloned recently. As pituitary tumours are classically associated with MEN1, we tested the presence of MEN1 gene mutations in sporadic tumours.

We studied 35 secreting and non-secreting sporadic adenomas. Among them 31 were found to be heterozygous for at least one MEN1 intragenic polymorphism (25 cases) or for a flanking gene polymorphism $(6$ cases). In only 4 cases there remained a possibility for homo- or hemizygosity. In one case only we identified a possible point mutation in the promoter region. As the patient originated in South America, we cannot exclude a polymorphism. Unfortunately, peripheral blood was not available to discriminate between these two possibilities.

Our results are consistent with previous reports that suggested that MEN1 gene mutation is a rare event in pituitary adenomas. Indeed, Zhuang et al. using single strand conformational polymorphism analysis found only 2 missense mutations among 4 pituitary adenomas with LOH for MEN1 in a sample of 39 sporadic tumours (9). Prezant et al. using dideoxy fingerprinting analysis (which is more sensitive) studied 45 sporadic tumours but failed to reveal any mutations in the coding sequence of MEN1 (10). Recently, in a sample of 31 sporadic tumours, Tanaka et al. detected only 1 nonsense mutation in a GH/PRL adenoma with $\mathrm{LOH}$ in $11 \mathrm{q} 13$ (11).

These results are disturbing taking into account that Boggild et al. found LOH on chromosome 11 in as many as about $20 \%$ of 88 sporadic adenomas (12). This discrepancy could have been explained by mutation(s) affecting the transcription level of the MEN1 gene. Therefore, we decided to sequence exon 1 and promoter but this experiment failed to reveal any mutation. While this work was in progress Prezant et al. also addressed this question by studying MEN1 mRNA expression which was found to be normal (10), and Asa et al. demonstrated by competitive reverse transcription-PCR that there was a lack of menin down-regulation in the majority of tumours with $\mathrm{LOH}$ at 11q13 (13).

To summarise, only 1 nonsense and 2 missense mutations (with unknown functional effects) were found in a total of 150 sporadic pituitary adenomas screened (including our series). Therefore, contrary to the other sporadic counterparts of typical MEN1 neoplasms, MEN1 gene mutation does not appear to be a common event explaining the formation of pituitary tumours. The discrepancy between $\mathrm{LOH}$ and mutation remains to be explained.

\section{Acknowledgements}

This work was supported by the Fonds National de la Recherche Scientifique (grants FRSM no. 3.4566.89 and 3.4628.93) and the Fonds de Recherche de la Faculté de Médecine de l'Université de Liège. We thank G Albert-Theate and J Jamin for expert technical assistance.

\section{References}

1 Spada A, Vallar L \& Faglia G. Cellular alterations in pituitary tumors. European Journal of Endocrinology 1994 13043-52.

2 Shimon I \& Melmed S. Genetic basis of endocrine disease: pituitary tumor pathogenesis. Journal of Clinical Endocrinology and Metabolism 199782 1675-1681.

3 Chandrasekharappa SC, Guru SC, Manickam P, Olufemi S-E, Collins FS, Emmert-Buck MR et al. Positional cloning of the gene for multiple endocrine neoplasia type 1. Science $1997276404-$ 407.

4 Lemmens I, Van de Ven WJ, Kas K, Zhang CX, Giraud S, Wautot V et al. Identification of the multiple endocrine neoplasia type 1 (MEN1) gene. Human Molecular Genetics 1997 61177-1183.

5 Heppner C, Kester MB, Agarwal SK, Debelenko LV, Emmert-Buck MR, Guru SC et al. Somatic mutation of the MEN1 gene in parathyroid tumors. Nature Genetics $199716375-378$.

6 Debelenko LV, Brambilla E, Agarwal SK, Swalwell JI, Kester MB, Lubensky IA et al. Identification of MEN1 gene mutations in sporadic carcinoid tumors of the lung. Human Molecular Genetics $199762285-2290$

7 Zhuang Z, Vortmeyer AO, Pack S, Huang S, Pham TA, Wang C et al. Somatic mutations of the MEN1 tumor suppressor gene in sporadic gastrinomas and insulinomas. Cancer Research 199757 4682-4686.

8 Courseaux A, Grosgeorge J, Gaudray P, Pannet AAJ, Forbes SA, Williamson $C$ et al. Definition of the minimal MEN1 candidate area based on a $5-\mathrm{Mb}$ integrated map of proximal 11q13. Genomics $199637354-365$.

9 Zhuang Z, Ezzat SZ, Vortmeyer AO, Weil R, Oldfield EH, Park W-S et al. Mutations of the MEN1 tumor suppressor gene in pituitary tumors. Cancer Research 1997 57 5446-5451.

10 Prezant TR, Levine J \& Melmed S. Molecular characterization of the MEN1 tumor suppressor gene in sporadic pituitary tumors. Journal of Clinical Endocrinology and Metabolism 1998831388 1391.

11 Tanaka C, Kimura T, Yang P, Moritani M, Yamaoka T, Yamada S et al. Analysis of loss of heterozygosity on chromosome 11 and infrequent inactivation of the MEN1 gene in sporadic pituitary adenomas. Journal of Clinical Endocrinology and Metabolism 1998 $832631-2634$.

12 Boggild MD, Jenkinson S, Pistorello M, Boscaro M, Scanarini M, McTernan P et al. Molecular genetics studies of sporadic pituitary tumors. Journal of Clinical Endocrinology and Metabolism 1994 78 387-392.

13 Asa SL, Somers K \& Ezzat S. The MEN1 gene is rarely downregulated in pituitary adenomas. Journal of Clinical Endocrinology and Metabolism 199883 3210-3212.

Received 13 November 1998

Accepted 12 February 1999 